International Research Journal of Management, IT \& Social Sciences
Available online at https://sloap.org/journals/index.php/irjmis/
Vol. 8 No. 6, November 2021, pages: 639-647
ISSN: 2395-7492
https://doi.org/10.21744/irjmis.v8n6.1966

\title{
Understanding the Impact of Zakat and Waqf as Economic Development of the Community in Rural Areas
}

Article history:

Submitted: 18 August 2021

Revised: 09 September 2021

Accepted: 31 October 2021

\section{Keywords:}

development; economy;

poor people; qualitative study;

zakat and waqf;

\begin{abstract}
This study discusses the understanding of the impact of Zakat and Waqf spending as part of the government's efforts with the community to develop the economy of the poor in rural areas. We use secondary data in answering the research questions from some zakat and people's economy publications from international publications, including journal articles, books, proceedings, and other data on internet sites that discuss the importance of zakat in the Islamic economy. After we found the data, we analyzed it using a phenomenological approach, a way to explore as much data as possible to solve problems with valid and reliable data findings. We choose the publication of data published ten years ago to be genuinely accurate and updated. Based on the findings and discussion data, we can summarize that zakat and the economy are two things that influence each other. As a result, the Islamic economy cannot be separated from Zakat and Waqf, which are potential instruments in improving the economy. With the existing economic problems, zakat and waqf can be an effective solution to overcome financial issues faced by the ummah.
\end{abstract}

International research journal of management, IT and social sciences (C) 2021. This is an open access article under the CC BY-NC-ND license (https://creativecommons.org/licenses/by-nc-nd/4.0/).

\section{Corresponding author:}

Nanang Yusroni,

Fakultas Ekonomi Universitas Wahid Hasyim, Semarang, Indonesia.

Email address: nanangyusroni@unwahas.ac.id

\footnotetext{
${ }^{a}$ Fakultas Ekonomi Universitas Wahid Hasyim, Semarang, Indonesia
}

${ }^{\mathrm{b}}$ Fakultas Ekonomi Universitas Wahid Hasyim, Semarang, Indonesia 


\section{Introduction}

Currently, zakat is increasingly taking a significant part in improving the community's economy, especially in Indonesia as a Muslim-majority country (Khasandy \& Badrudin, 2019). As stated by Walker \& BantebyaKyomuhendo (2014), the idea of zakat has three main measures: the measurement of other world individuals, social statures, and financial heights. Zakat is a method of loving and filtering one's soul. With zakat, individual benefits will increase because zakat encourages individuals to have a high hard work attitude. In monetary measurement, Widiyono (2020), explained that zakat has two main ideas: equitable financial development and sharing components in the economy. Whenever concentrated more deeply, the third measure positively correlates with the limits of human improvement, consisting of well-being, training, and fair expectations for everyday comfort (Arfah et al., 2020; Pratama \& Mandaasari, 2020).

After all, zakat is also related to financial and economic development factors (Jedidia \& Guerbouj, 2020). Noor \& Saad (2016), states that zakat affects business and creation, savings, and utilization. On the business side, zakat can be used as a source of beneficial assets to advance miniature zakat recipient organizations. The progress of this minibusiness can help the Indonesian economy and has quite superior flexibility in an economic emergency. In terms of utilization, zakat arrangements can animate an increase in total interest. Increasing interest in zakat will empower expansion on the supply side, with the aim that the economy continues to develop and be evenly distributed, especially for people in rural areas in Indonesia (Wirda \& Rivai, 2019).

However, the continued use of zakat as an instrument to build prosperity improvement will be influenced by the presentation of zakat organizations and their ability to subsidize themselves. Indonesia is one of the countries with colossal zakat potential. Based on a study led by the National Amil Zakat Agency, the Bogor Agricultural Institute, and the Islamic Development Bank in 2011, the potential for community zakat reaches IDR 217.3 trillion every year (Canggih et al., 2017; Pemayun et al., 2019). Although the recognition of zakat is still below one percent of the projection, the development of community zakat continues to show critical actions. Beik \& Arsyianti (2013), noted that for 2012, the collected zakat reserves reached Rp. 2.2 trillion, an increase from the previous year of IDR 1.7 trillion, and in 2010 amounted to (Andriyanto, 2011). Many consider that destitution is proof of financial treachery and disparity. There is nothing off about that supposition because the truth of the matter is that it is. The law of the market causes an inconsistent circulation of the economy.

However, when viewed from another perspective, the presence of the Poor and the Rich resembles different sides of the coin that (supposedly) complement each other. Both are available in financial conditions that are far apart, but there is a kind of magnet that attracts each other so that they collaborate (Toutounchian, 2011). Obligations and Zakat, among others, become a connecting tool between the rich and the poor in the state as an Islamic religion (Lanjouw \& Cockburn, 2001; Kamphuis et al., 2010). Despite their unique stances, each has almost the same venerable goals, in particular, to aim at poverty reduction and the equitable distribution of government aid (Bremer, 2015). According to the historical background of Islam at the time of the Prophet Muhammad and the caliphate, Zakat is the main tax collection framework added to every Muslim besides Jizya and Kharaj. Jizya and Kharaj are required of non-Muslims under Islamic principles. At that time, the current practice merged with the advanced tax assessment framework, in which the state applied fees at a higher rate than the zakat rate. The types of assessment are also more diverse than Zakat, with various strategies and distributions (Abdelbaki, 2013).

Zakat is an important thing that is the mainstay of Islam that must be done by every Muslim who is good financially or fulfills needs (Subuh, 2016). The distribution of Zakat according to Islamic guidance is only to help eight groups of people who are entitled. Especially the poor, the poor (people who have resources/salaries but not enough to solve their problems), Amil (zakat administrators), Muallaf (people who have recently received Zakat). Islam), Riqab (slaves or slaves), Gharimin (people who are in debt and find it challenging to repay), Fisabilillah (people or bodies who fight in the cause of Allah), and Ibn Sabil (travelers or explorers). At the same time, retribution is a burden imposed by public authorities on every citizen to support all areas of life and the state (Kalimah, 2020).

Although the development is critical, the recognition of the variety of zakat is still very low compared to the tremendous ability of zakat payers. In 2015, BAZNAS projected that the community's zakat potential would reach IDR 286 trillion, but the amount collected is IDR 3.7 trillion or only 1.3\% of its latent capacity (Muhtar, 2016). These figures may not reflect the original recognition of Zakat installments. Various elements must also be considered related to the low zakat installments in Indonesia (Nasar, 2018). First of all, it may be due to avoiding the double burden of tax collection. Second, there is still no public trust in the Amil Zakat institution. Third, many Muzakki may decide to distribute zakat directly to Mustahik without Amil delegation. Fourth, the low consistency of Muslims because there is no understanding of how to pay zakat. Zakat and levies are significant and play an essential role in overcoming 
financial imbalances and needs in a country. Especially for Indonesia, the country with the largest Muslim population on the planet (Alaydrus, 2017).

With regards to the state, it is a commitment for each resident to make good on charges. In the meantime, with regards to religion, there is not a remotely good excuse for Muslims not to pay zakat, mainly if all that they give can lessen their available pay. Having confidence zakat and expenses won't make the payer poor; they will help many individuals. Given the importance of zakat to advance the community's economy, every Muslim must at least understand and carry out the commandment of zakat because zakat and other infaq are very influential on the country's economy, especially in Indonesia, where the majority of the people adhere to Islam (Purwati, 2015). Zakat and community economic empowerment. With a good understanding of how zakat can increase the income of poor people due to their low-income level and ability to do business, the additional income will be used entirely to buy essential goods and services. Thus, the study of zakat will be helpful to both academics and other practitioners so that zakat can improve the community's economy manifold, especially Muslims in remote parts of the country (Salihin, 2019).

\section{Materials and Methods}

In this section, we are going to explain how this study was done. This study discusses the understanding of the impact of Zakat and Waqf's spending as part of the government's efforts with the community to develop the economy of the poor in rural areas (Johari et al., 2014; Ambrose et al., 2015). We use secondary data in answering the research questions from many zakats and people's economy publications from international publications, including journal articles, books, proceedings, and other data on internet sites that discuss the importance of zakat in the Islamic economy. After we found the data, we analyzed it using a phenomenological approach to explore as much data as possible so that we can solve the problem with valid and reliable data findings (Hyett et al., 2014). We choose data publications published ten years ago so that the data is genuinely valid and up-to-date. Based on the findings and discussion data, we can summarize that zakat and the economy are two things that influence each other. As a result, the Islamic economy cannot be separated from Zakat and Waqf, which are potential instruments in improving the economy (Alim, 2015; Mahat et al., 2015).

\section{Results and Discussions}

\section{Understanding zakat}

The definition of Zakat comes from the word zakat, which means to develop; another essential meaning in the Qur'an, Zakat is sacred from transgression, while in Islamic law books, Zakat is characterized as developing, heavenly, creating, and liking (Ahmad, 2017). Zakat develops and builds; if it is articulated, take alarm, it implies that plants develop and create. If you say zakat al-nafaqah. That is, a life develops and increases if it is blessed with Zakat according to the well-known term, in particular giving an unusual part of a unique property with extraordinary arrangements, and part of it on extraordinary occasions for its mustahiq (Purwanto, 2014). So when the verses of the Qur'an or al-hadith use the word Zakat which is identified with the use of resources, it implies only one and that, especially Zakat with that definition (Mardliyaturrohmah, 2020).

If it is associated with the spirit, it means the sanctity of the spirit-for example, deep sympathy on the part of the ummah and the sanctity of transgression. Moreover, the teachings of a prophet are obedient individuals, Q.s. 19/Maryam: 13 And the different implications of the word zakat if it is not identified with the consumption of certain assets (Widiastuti \& Rosyidi, 2015). Zakat is very important for a property that every certified Muslim must give to specific individuals under certain conditions. The abundance given will tidy up every resource that is zakat, and follow its development (Toya \& Skidmore, 2007; Deeds \& Hill, 1996). The assets for which zakat must be issued are (a) gold, silver, and cash, (b) supplies, (c) pets, (d) agricultural and marine products and the consequences of their management, (e) mining goods and merchandise. Understanding Infaq from the word nafaqa or nafiqa yanfiqu nafqan ash-syaiu means sold out (Syahrir, 2017). Nafaqa ar-rajulu means passing, nafaqa al-jarh means stripping wounds, nafiqa or naffaqa alyarbu' means creeping in and out of horror. Anfaqa sadhu means exhausted, istanfaqa al-mal means spending a lot, Naafaqa means acting dishonestly (Djafri et al., 2020).

Tanaffaqa and intafaqa mean to remove, An-nafqu means to open through, An-nifqu means to destroy quickly, annafqah means a place for musk oil, An-Nifq means pietism, and alinfaq means spending. Infaq, from an overall

Yusroni, N., \& Chadhiq, U. (2021). Understanding the impact of zakat and waqf as economic development of the community in rural areas. International Research Journal of Management, IT and Social Sciences, 8(6), 639-647. https://doi.org/10.21744/irjmis.v8n6.1966 
perspective, is short mal ilal hajah (arranging or providing resources to solve problems) (Rahman, 2015). Infaq can mean both positive and negative. He is spending a lot of money to fund disobedience, even to fight Islam, including faq. In this way, there are infaq fi sabilis syaithan (infaq in the devil's method). For example, another important Abu Lahab, when boasting about reporting the rewards for those who could kill Muhammad, he said "La Anfaqonnaha fi 'adawati Muhammad". "I will spend it on Muhammad, instead of spending a lot in the goodness that pleases Allah" (Widiastuti \& Rosyidi, 2015).

\section{Zakat and Wakf help the poor}

Furthermore, infaq can be provided by the receiving individual, regardless of whether they have high or low pay under broad or limited conditions. In connection with this, it is felt, while Mandatory Infaq is infaq from payments that do not depend on the commitment of zakat. In addition, the most important infaq is the spouse's infaq to his better brother, children, and neighbors (Ritonga \& Mahyudin, 2020). In line with that infaq, with the meaning of zakat and not zakat but as old. Furthermore, there are circumcision infaq, especially standard foundations, and obligatory infaq (not zakat) and circumcision infaq in the sense of shadaqah, infaq, for children and spouses, direct relationships, the poor, and ibn sabil. While infaq circumcision means sadaqah circumcision Q.S. 2 (Albaqarah). Understanding Waqf Understanding waqf in the language is the word al-waqf, which contains the meaning of al-habsu (hold) or al-man'u (hold). The word al-waqf is the maşdar of the waqftu al-dābah waqfan sentence, which means habastuha fi sabilillah.

People who do waqf are called waqif if they avoid walking, while the goods that are donated are called mauqf. The plural form of the word waqf is auqaf. As the word of Allah SWT: wāqifühum innahum masūlūn, what is important is ahbisūhum 'an al-sair (restraining them from walking around) (Abdul-Karim, 2010). Regarding the use of the word auqafa with hamzah for the benefit of waqf, it is an inappropriate word. The articulation of tahbis al-syai' (holding something) implies yabqā aşluhu spreading his head of wealth (Visser, 2019). In a hadith that reads: "Surely (Khalid Wadah Walid) has maintained (database) protection and his allies in the way of Allah," the word guard here means enriching him in the way of Allah. Benefits according to Islamic teachings. People who have given their property generally do not qualify for merchandise or goods in waqf because apart from denying their rights to previous sources, this title is also special, namely specifically to help others or for the public interest (Pipes, 2017).

\section{Zakat management}

The system of Islamic financial institutions energizes job creation through two channels, in particular: the creation of fixed-wage jobs and the establishment of entrepreneurial freedom. In addition, one of the main institutional systems in Islamic economics for job creation is zakat (Widiastuti et al., 2018). So far, the administration of zakat, which relies on Law Number 38 of 1999 concerning Zakat Management, is considered to have not been following the development of legal requirements in the eyes of the public, so that it must be replaced. The organizers of zakat regulated in this Law include the arrangement, selection, transportation, and use (Fahlefi et al., 2019). With the ultimate goal of achieving the goals of zakat executives, the National Amil Zakat Agency is framed to be located at the state capital, general, and local or city level. Bada zakat is a non-primary government organization that is autonomous and capable of serving the President through the Minister. The zakat agency is an institution that is approved to complete the zakat of business entities broadly (Lenap et al., 2020).

The point of view that helps zakat work is Miniature Economic Zakat. From a miniature monetary perspective, zakat has significantly different financial consequences, considering its total use, public reserve funds, effort, and total creation (Hassan et al., 2017). The main consequence of zakat is its effect on total utilization. In an Islamic economy where zakat is applied, the local area will be separated into two groups of payments, namely zakat payers and certain zakat recipients (Tseng et al., 2018; Martin, 2016). Musyawarah, who are obliged to pay zakat, will transfer part of their salary to the mushtahik, who is the recipient of zakat. This will build discretionary cash flow mustahik. Expansion of discretionary cash flow will expand utilization and, at the same time, allow mustahik to start saving (Ahmed \& Zakaria, 2021).

In the long term, the exchange of zakat will build on the assumption of payment and the level of abundance of mustahik, which makes its utilization much higher. It mostly has solid hypothetical and observational assistance (Muthohar, 2019). In the ordinary Keynesian utilization hypothesis, utilization is controlled exclusively by the current level of payouts (direct payout speculation). In the present richer usage hypothesis, buyers are considered to be completely level-headed and will maintain a generally stable usage design throughout their lives (Hamdani, 2020). Therefore, the current salary is only one of the determinants of utilization consumption. Abundance and expected 
future payments also play an important role in determining usage. With this in mind, the Life Cycle-Permanent Income Hypothesis predicts that the minimal propensity to devour is very small (Moav \& Neeman, 2012).

Various studies have resolved that the total utilization rate in the Islamic economy will be higher (Ridlo, 2014). This is because the MPC and normal affinity to burn-through sharia economy is higher than the ordinary economy. The debate is very basic, especially by acknowledging that the MPC of mustahik is much higher than muzaki. If you move a certain level of payment from meetings with low MPC to meetings with high MPC, usually the net effect is positive, especially MPC will be higher (Mudhiiah, 2016). In addition, the APC of the poor group is higher than the APC of the rich group. So the exchange from the rich to the helpless social gathering will build a total APC of regular income earners from the financial aspect that comes from expanding the utilization of the poor.

This will directly expand interest in labor and products from the poor, which are generally basic needs such as food, clothing, and safe houses (Kalsum, 2018). The attraction of people's basic needs, which are more identified with zakat, will affect the creation of labor creation and products that are distributed in the economy. Collection of Zakat To understand the collection or commonly referred to as fundraising, we can first refer to the English dictionary (Nisa, 2019). Fundraising translates as fundraising. Why is raising the money necessary? Collection of money is needed to finance the work program and operations of an institution. In essence, the survival of an institution depends on the extent to which fundraising is carried out by the institution depending on the extent to which the fundraising is carried out on a non-profit basis (Tomlinson \& Schwabenland, 2010).

\section{Zakat distribution system}

Zakat reserves were at first overwhelmed by destructive circulation designs, yet in today's later execution, zakat has started to be created with a practical example of dissemination of zakat reserves (Kashif et al., 2018). The conveyance of useful zakat is the giving of zakat that can make the beneficiary produce something constantly. Constantly, with the zakat resources, he gets. The framework is an assortment of parts or parts, both physical and non-physical, that are interconnected with one another and cooperate in concordance to accomplish an objective. Simultaneously, dissemination is the conveyance or circulation of something to invested individuals (Susanto, 2015). Consequently, the zakat dispersion framework implies an assortment or part, both physical and non-physical, interconnected with one another and cooperating in amicability to appropriate the gathered zakat to specific gatherings in accomplishing the financial objectives of zakat assortment. The zakat circulation framework has a reason and reason (Sari et al., 2013).

The team is assembled in management that can move all elements of the company's organization from operations, production, management, and marketing. Gathering positions in nonprofit organizations are similar to marketing positions in corporate organizations (Owoyemi, 2020). However, there is a fundamental difference between fundraising in a nonprofit organization and marketing in a corporate organization. The collection is the process of influencing the community, both individuals and representatives of the community or institutions, to channel funds to an organization. The word influencing society has many meanings; First, in the sentence above, influencing can be interpreted as informing the public about the ins and outs of the existence of a nonprofit organization or zakat management organization working on religious and social grounds, not focusing on profit). and profit, then this organization becomes part of a nonprofit organization (Rachman \& Salam, 2018).

Destructive dissemination designs at first ruled zakat Distribution System Zakat reserves, yet in today's later execution, zakat has started to be created with a practical conveyance example of zakat reserves (Kashif et al., 2018). The dissemination of helpful zakat is the giving of zakat that can make the beneficiary produce something constantly. Persistently, with the zakat resources, he gets. The framework is an assortment of parts or parts, both physical and nonphysical, that are interconnected with one another and cooperate in amicability to accomplish an objective. Simultaneously, circulation is dispersing something to invested individuals (Susanto, 2015). Hence, the zakat conveyance framework implies an assortment or part, both physical and non-physical, that are interconnected and cooperate in agreement to appropriate the gathered zakat to specific gatherings in accomplishing the financial objectives of zakat assortment. The zakat conveyance framework has a reason and reason (Sari et al., 2013).

\section{Community empowerment Zakat}

The principal component of strengthening the local area is to allow for power and the establishment of local boundaries. The two components cannot be separated; if the region that has received power has not or could not practice this position, the results are also not optimal (Zaenal et al., 2018). Community groups are in a minor situation because of the absence of these two components, being a particular position and limit. This condition is often alluded to as a weak

Yusroni, N., \& Chadhiq, U. (2021). Understanding the impact of zakat and waqf as economic development of the community in rural areas. International Research Journal of Management, IT and Social Sciences, 8(6), 639-647. https://doi.org/10.21744/irjmis.v8n6.1966 
or weak area, so they do not have the opportunity to face their future. It is seen as the main driver of the powerless everyday environment. To gain strength and oversee progress, regions must be involved through a cycle of strengthening (Ansori, 2018).

As Korten wants to think, understanding power is not enough of a distributive measure; in the individual's words, power can be defined as an individual's capacity to influence others (Furqani et al., 2019). As he wanted to think, to understand the strengthening thinking that was being developed, the strength in the generative measurement was much more significant. One meeting will only gain additional or increase the strength of another meeting. The weak collection will get extra strength or reinforcement simply by reducing the strength in the group of power holders (Sholeh, 2021). The state must give part of its position or part of its capacity to the local area through the strengthening system. This is similar to the general power of having a decent amount of cake, and it is circulated to many gatherings so that specific gatherings get an extra piece of cake to be completed by reducing the other party's piece of cake (Pertiwi et al., 2020).

\section{Conclusion}

In this final section, we summarize the results of our study to discuss how the impact of zakat and infaq in empowering the ummah, especially the economy among rural communities. We believe our discussion has answered the core objective of this study with a series of data and information presentations that we obtained from a review of secondary data from many international journal papers that seriously discuss zakat and the virtues of zakat in managing public funds so that poverty can be overcome among rural Muslims. We prove it by a study involving a descriptive qualitative data analysis system (Greening et al., 1996; Sun et al., 2020). Until finally, we can summarize, among other things, how zakat is a tool for empowering the ummah. How is the distribution of zakat following Islamic guidelines and the Sunnah of the Prophet? Besides that, we also discussed the management of zakat, which has been regulated in Islamic law and supported by the state through legal provisions, how the role of zakat has an impact on poverty alleviation of the ummah in villages and remote areas. All of our explanations, of course, start with an understanding of what zakat and other infaq are in Islam which has been implemented as part of reducing and helping the poor.

\section{Conflict of interest statement}

The authors declared that they have no competing interests.

Statement of authorship

The authors have a responsibility for the conception and design of the study. The authors have approved the final article.

\section{Acknowledgments}

We thank all supports from the university and the minister of Higher Education and research. Without their support both academically and financially, we can not be able to finish the project accordingly. 


\section{References}

Abdelbaki, H. H. (2013). The impact of zakat on poverty and income inequality in Bahrain. Rev. Integr. Bus. Econ. Res, 2(1).

Abdul-Karim, S. (2010). Contemporary shari'ah structuring for the development and management of waqf assets in Singapore (Doctoral dissertation, Durham University).

Ahmad, D. M. (2017). Makna Sosial Zakat Di Kalangan Muzaki Konvensional (Studi Kualitatif Pembagian Zakat Secara Langsung dan Massal di Kota Surabaya) (Doctoral dissertation, Universitas Airlangga).

Ahmed, T. A. I., \& Zakaria, M. S. B. (2021). Using Blockchain For Managing Zakat Distribution: A Juristic Anlytical Study. Al Hikmah: International Journal of Islamic Studies and Human Sciences, 4(2), 1-25.

Alaydrus, M. Z. (2017). Pengaruh zakat produktif terhadap pertumbuhan usaha mikro dan kesejahteraan mustahik pada badan amil zakat kota pasuruan jawa timur (Doctoral dissertation, UNIVERSITAS AIRLANGGA).

Alim, M. N. (2015). Utilization and accounting of Zakat for productive purposes in Indonesia: A review. ProcediaSocial and Behavioral Sciences, 211, 232-236. https://doi.org/10.1016/j.sbspro.2015.11.028

Ambrose, A. H. A. A., Aslam, M., \& Hanafi, H. (2015). The possible role of waqf in ensuring a sustainable Malaysian federal government debt. procedia economics and finance, 31, 333-345. https://doi.org/10.1016/S22125671(15)01205-8

Andriyanto, I. (2011). Strategi pengelolaan zakat dalam pengentasan kemiskinan. Walisongo: Jurnal Penelitian Sosial Keagamaan, 19(1), 25-46.

Ansori, T. (2018). Pengelolaan Dana Zakat Produktif untuk Pemberdayaan Mustahik pada Lazisnu Ponorogo. Muslim Heritage, 3(1), 177-196.

Arfah, A., Olilingo, F. Z., Syaifuddin, S., Dahliah, D., Nurmiati, N., \& Putra, A. H. P. K. (2020). Economics during global recession: sharia-economics as a post Covid-19 agenda. The Journal of Asian Finance, Economics, and Business, 7(11), 1077-1085.

Beik, I. S., \& Arsyianti, L. D. (2013). Optimization of zakat instrument in Indonesia's poverty alleviation programme. In Poverty Alleviation-Academic Conference.

Bremer, J. (2015). Zakat and economic justice: Emerging international models and their relevance for Egypt.

Canggih, C., Fikriyah, K., \& Yasin, A. (2017). Potensi dan realisasi dana zakat indonesia. Al-Uqud: Journal of Islamic Economics, 1(1), 14-26.

Deeds, D. L., \& Hill, C. W. (1996). Strategic alliances and the rate of new product development: An empirical study of entrepreneurial biotechnology firms. Journal of business venturing, 11(1), 41-55. https://doi.org/10.1016/08839026(95)00087-9

Djafri, M. T., Patahuddin, A., Aqbar, K., \& Syarifuddin, C. (2020). Zakat Harta dari Hasil Undian Berhadiah dalam Perspektif Hukum Islam. BUSTANUL FUQAHA: Jurnal Bidang Hukum Islam, 1(3), 390-415.

Fahlefi, R., Hasan, A., \& Alimin, A. (2019). Management Model Of Zakat Collection And Its Distribution For Zakat Agency/Management Model of Zakat Collection and Its Distribution for Zakat Agency. Uluslararası Ekonomi İsletme ve Politika Dergisi, 3(2), 171-182.

Furqani, H., Mulyany, R., \& Yunus, F. (2019). Zakat for Economic Empowerment (Analyzing the Models, Strategy and Implications of Zakat Productive Program in Baitul Mal Aceh and Baznas Indonesia). Iqtishadia: Jurnal Kajian Ekonomi dan Bisnis Islam STAIN Kudus, 11(2), 391-411.

Greening, D. W., Barringer, B. R., \& Macy, G. (1996). A qualitative study of managerial challenges facing small business geographic expansion. Journal of business venturing, 11(4), 233-256. https://doi.org/10.1016/08839026(95)00108-5

Hamdani, L. (2020). Zakat Blockchain: A Descriptive Qualitative Approach. EkBis: Jurnal Ekonomi dan Bisnis, 4(2), 492-502.

Hassan, S., Amuda, Y. J., \& Parveen, R. (2017). Persecuted muslim minority: Zakat, waqf, and sadaqah as financial instrument for human development. International Journal Of Applied Business And Economic Research, 15(25).

Hyett, N., Kenny, A., \& Dickson-Swift, V. (2014). Methodology or method? A critical review of qualitative case study reports. International journal of qualitative studies on health and well-being, 9(1), 23606.

Jedidia, K. B., \& Guerbouj, K. (2020). Effects of zakat on the economic growth in selected Islamic countries: empirical evidence. International Journal of Development Issues.

Johari, F., Ab Aziz, M. R., \& Ali, A. F. M. (2014). A review on literatures of zakat between 2003-2013. Library Philosophy and Practice, $0 \_1$.

Kalimah, S. (2020). Manajemen Zakat dalam Upaya Peningkatan Kesejahteraan Umat. Salimiya: Jurnal Studi Ilmu Keagamaan Islam, 1(2), 37-63.

Yusroni, N., \& Chadhiq, U. (2021). Understanding the impact of zakat and waqf as economic development of the community in rural areas. International Research Journal of Management, IT and Social Sciences, 8(6), 639-647. https://doi.org/10.21744/irjmis.v8n6.1966 
Kalsum, U. (2018). Distribusi Pendapatan dan Kekayaan dalam Ekonomi Islam. Li Falah: Jurnal Studi Ekonomi dan Bisnis Islam, 3(1), 41-59.

Kamphuis, C. B., Mackenbach, J. P., Giskes, K., Huisman, M., Brug, J., \& Van Lenthe, F. J. (2010). Why do poor people perceive poor neighbourhoods? The role of objective neighbourhood features and psychosocial factors. Health \& place, 16(4), 744-754. https://doi.org/10.1016/j.healthplace.2010.03.006

Kashif, M., Jamal, K. F., \& Rehman, M. A. (2018). The dynamics of Zakat donation experience among Muslims: a phenomenological inquiry. Journal of Islamic Accounting and Business Research.

Khasandy, E. A., \& Badrudin, R. (2019). The influence of zakat on economic growth and welfare society in Indonesia.

Lanjouw, J. O., \& Cockburn, I. M. (2001). New pills for poor people? Empirical evidence after GATT. World Development, 29(2), 265-289. https://doi.org/10.1016/S0305-750X(00)00099-1

Lenap, I. P., Sasanti, E. E., Karim, N. K., \& Sari, N. K. (2020). Zakat Disbursement Efficiency Based on Zakat Core Principles in Managing Zakat Funds in Baznas of West Nusa Tenggara Province. Jurnal Akuntansi dan Bisnis, 20(1), 103-116.

Mahat, M. A., Jaaffar, M. Y., \& Rasool, M. S. A. (2015). Potential of micro-waqf as an inclusive strategy for development of a nation. Procedia Economics and Finance, 31, 294-302. https://doi.org/10.1016/S22125671(15)01193-4

Mardliyaturrohmah, B. (2020). Pengaruh pemahaman zakat, pendapatan, religiusitas, kepercayaan, dan lingkungan sosial Muzaki terhadap minat membayar zakat: studi pada pemilik kos di RW 05 Jemur Wonosari Surabaya (Doctoral dissertation, UIN Sunan Ampel Surabaya).

Martin, C. J. (2016). The sharing economy: A pathway to sustainability or a nightmarish form of neoliberal capitalism?. Ecological economics, 121, 149-159. https://doi.org/10.1016/j.ecolecon.2015.11.027

Moav and, O., \& Neeman, Z. (2012). Saving rates and poverty: The role of conspicuous consumption and human capital. The Economic Journal, 122(563), 933-956.

Mudhiiah, K. (2016). Analisis Sejarah Pemikiran Ekonomi Islam Masa Klasik. IQTISHADIA, 8(2).

Muhtar, M. (2016). Penilaian Aset dalam Akutansi Syariah untuk Menentukan Besarnya Zakat Perusahaan: Historical Cost vs. Current Value (Studi Kasus Pada CV. Sedayu Makassar) (Doctoral dissertation, Universitas Islam Negeri Alauddin Makssar).

Muthohar, A. M. (2019). Analysis of influence of intrinsic aspect, demography aspect and service of zakat institution toward zakat payment to zakat institution. INFERENSI: Jurnal Penelitian Sosial Keagamaan, 13(1), 25-50.

Nasar, M. F. (2018). Capita Selecta Zakat: Esei-Esei Zakat Aksi Kolektif Melawan Kemiskinan. Gre Publishing.

Nisa, S. K. (2019). Studi komparasi pengelolaan penghimpunan zakat, infaq, shadaqah di Lazismu dan Lazisnu Kabupaten Kendal Tahun 2018 (Doctoral dissertation, UIN Walisongo).

Noor, A. M., \& Saad, R. A. J. (2016). The mediating effect of trust on the relationship between attitude and perceived service quality towards compliance behavior of zakah. International Journal of Economics and Financial Issues, 6(7S).

Owoyemi, M. Y. (2020). Zakat management: The crisis of confidence in zakat agencies and the legality of giving zakat directly to the poor. Journal of Islamic Accounting and Business Research.

Pemayun, A. A. G. P., Suryanata, I. G. N. P., Nurcita, I. K., \& Yunita, P. I. (2019). Economic, social and cultural changes in society due to sustainable tourism development. International Journal of Social Sciences and Humanities, 3(3), 117-127. https://doi.org/10.29332/ijssh.v3n3.359

Pertiwi, R. S., Herianingrum, S., \& Kusuma, A. (2020). Zakat and Youth Empowerment. International Journal of Zakat, 5(2), 51-66.

Pipes, D. (2017). In the path of God: Islam and political power. Routledge.

Pratama, I. G. S., \& Mandaasari, I. A. C. S. (2020). The impact of tourism development on the economic, cultural and environmental aspects of local communities. International Research Journal of Management, IT and Social Sciences, 7(1), 31-36. https://doi.org/10.21744/irjmis.v7n1.819

Purwanto, Y. (2014). Memaknai pesan spiritual ajaran agama dalam membangun karakter kesalehan sosial. Jurnal Sosioteknologi, 13(1), 41-46.

Purwati, S. (2015). Zakat dan pemberdayaan ekonomi masyarakat (pelaksanaan zakat padi di Desa Sukolilan Kecamatan Patebon Kabupaten Kendal) (Doctoral dissertation, UIN Walisongo).

Rachman, M. A., \& Salam, A. N. (2018). The Reinforcement of Zakat Management through Financial Technology Systems. International Journal of Zakat, 3(1), 57-69. 
Rahman, T. (2015). Akuntansi Zakat, Infak dan Sedekah (PSAK 109): Upaya Peningkatan Transparansi dan Akuntabilitas Organisasi Pengelola Zakat (OPZ). Muqtasid: Jurnal Ekonomi Dan Perbankan Syariah, 6(1), 141164.

Ridlo, A. (2014). Zakat Dalam Perspektif Ekonomi Islam. Al-'Adl, 7(1), 119-137.

Ritonga, M. A., \& Mahyudin, E. (2020). Review of Zakat, Infaq, and Shadaqah as a Similar Terminology.

Salihin, A. (2019). Pengaruh Dow Jones Islamic Market (DJIM), Kurs, Dan Harga Emas Dunia Terhadap Jakarta Islamic Indeks (JII) Periode 2016-2018. Jurnal Istiqro: Jurnal Hukum Islam, 5(2), 114-126.

Sari, M. D., Bahari, Z., \& Hamat, Z. (2013). Review on Indonesian zakah management and obstacles. Social Sciences, 2(2), 76-89.

Sholeh, M. (2021). Zakat Empowerment Strategy to Improve the Empowerment of the Poor Community. Turkish Journal of Computer and Mathematics Education (TURCOMAT), 12(9), 1053-1060.

Subuh, B. M. (2016). Manajemen Zakat di Badan Amil Zakat Nasional (BAZNAS) Daerah Kota Tangerang Selatan. Skripsi S1 Fakultas Ekonomi dan Binsis, Universitas Islam Negeri Syarif Hidayatullah Jakarta.

Sun, N., Wei, L., Shi, S., Jiao, D., Song, R., Ma, L., ... \& Wang, H. (2020). A qualitative study on the psychological experience of caregivers of COVID-19 patients. American journal of infection control, 48(6), 592-598. https://doi.org/10.1016/j.ajic.2020.03.018

Susanto, A. (2015). What factors influence the quality of accounting information. International Journal of Applied Business and Economic Research, 13(6), 3995-4014.

Syahrir, S. (2017). Pemahaman Masyarakat Terhadap Kewajiban Zakat Di Kecamatan Maritengngae Kabupaten Sidenreng Rappang (Doctoral dissertation, Univeritas Islam Negeri Alauddin Makassar).

Tomlinson, F., \& Schwabenland, C. (2010). Reconciling competing discourses of diversity? The UK non-profit sector between social justice and the business case. Organization, 17(1), 101-121.

Toutounchian, I. (2011). Islamic Money and Banking: Integrating Money in Capital Theory (Vol. 760). John Wiley \& Sons.

Toya, H., \& Skidmore, M. (2007). Economic development and the impacts of natural disasters. Economics letters, 94(1), 20-25. https://doi.org/10.1016/j.econlet.2006.06.020

Tseng, M. L., Tan, R. R., Chiu, A. S., Chien, C. F., \& Kuo, T. C. (2018). Circular economy meets industry 4.0: can big data drive industrial symbiosis?. Resources, Conservation and Recycling, 131, 146-147. https://doi.org/10.1016/j.resconrec.2017.12.028

Visser, H. (2019). Islamic finance: Principles and practice. Edward Elgar Publishing.

Walker, R., \& Bantebya-Kyomuhendo, G. (2014). The shame of poverty. Oxford University Press, USA.

Widiastuti, T., \& Rosyidi, S. (2015). Model Pendayagunaan Zakat Produktifitas oleh Lembaga Zakat dalam Meningkatkan Pendapatan Mustahiq. Jurnal Ekonomi dan Bisnis Islam (JEBIS), 1(1), 89-101.

Widiastuti, T., Mawardi, I., Robani, A., \& Rusydiana, A. S. (2018). Optimization of Zakat fund management in regional Zakat institution. Humanities \& Social Sciences Reviews, 6(2), 133-139.

Widiyono, T. (2020). The Role of Sharia Banking Institution in Zakat Collection as a Source of Economic Development. In International Conference on Community Development (ICCD 2020) (pp. 751-754). Atlantis Press.

Wirda, F., \& Rivai, H. A. (2019). Competitive advantage: Mediation effect between entrepreneurial competency and business performance creative industries in West Sumatera-Indonesia. Academy of Entrepreneurship Journal, 25(1), 1-11.

Zaenal, M. H., Astuti, A. D., \& Sadariyah, A. S. (2018). Increasing urban community empowerment through changing of poverty rate index on the productive zakat impact. In IOP Conference Series: Earth and Environmental Science (Vol. 106, No. 1, p. 012104). IOP Publishing.

Yusroni, N., \& Chadhiq, U. (2021). Understanding the impact of zakat and waqf as economic development of the community in rural areas. International Research Journal of Management, IT and Social Sciences, 8(6), 639-647. https://doi.org/10.21744/irjmis.v8n6.1966 